\title{
Shallow lacustrine system of the Permian Pedra de Fogo Formation, Western Gondwana, Parnaíba Basin, Brazil
}

\author{
Raphael Neto Araújo a, c, *, Afonso César Rodrigues Nogueira ${ }^{\text {a, b }}$, José Bandeira ${ }^{\mathrm{b}}$, \\ Rômulo Simões Angélica a, b \\ a Programa de Pós-graduação em Geologia e Geoquímica (PPGG), Universidade Federal do Pará (UFPA), Rua Augusto Corrêa, 01, Bairro do Guamá, CEP \\ 66075-110, Belém, Pará, Brazil \\ ${ }^{\mathrm{b}}$ Faculdade de Geologia (FAGEO), Universidade Federal do Pará (UFPA), Rua Augusto Corrêa, 01, Bairro do Guamá, CEP 66075-110, Belém, Pará, Brazil \\ c Companhia de Pesquisa de Recursos Minerais (SGB/CPRM), Avenida Dr. Freitas, 3645, Bairro do Marco, CEP 66095-110, Belém, Pará, Brazil
}

\section{A R T I C L E I N F O}

\section{Article history:}

Received 17 March 2015

Received in revised form

29 November 2015

Accepted 27 January 2016

Available online 8 February 2016

\section{Keywords:}

Parnaíba Basin

Balsas Group

Pedra de Fogo Formation

Sedimentary facies

\begin{abstract}
A B S T R A C T
The Permian Period of the Parnaíba Basin, northern Brazil, represented here by deposits from the Pedra de Fogo Formation, records important events that occurred in Western Gondwana near its boundary with the Mesozoic Era. The analysis of outcrop based facies from the Permian Pedra de Fogo Formation, which is $100 \mathrm{~m}$ thick, carried out along the eastern and western borders of the Parnaiba Basin, allowed the identification of eleven sedimentary facies, which were grouped into three distinct facies associations (FA), representative of a shallow lacustrine system associated with mudflats and ephemeral rivers. Bioturbation, desiccation cracks, silcretes and various siliceous concretions characterize the Pedra de Fogo deposits. The FA1 mudflat deposits occur predominantly at the base of the Pedra de Fogo Formation and consist of laminated claystone/mudstone, mudcrack-bearing sandstones/mudstones and sandstones exhibiting cross-lamination, massive and megaripple bedding. Popcorn-like silicified nodules and casts indicate evaporite deposits. Other common features are silica concretions, silicified tepees and silcretes. FA2 represents nearshore deposits and consists of fine-grained sandstones with evenly parallel lamination, climbing ripple cross-lamination, massive and megaripple bedding and mudstone/siltstone showing evenly parallel lamination. FA3 refers to wadi/inundite deposits, generally organized as finingupward cycles of metric size, composed of conglomerates and medium-grained pebbly sandstones showing massive bedding and cross-stratification, as well as claystone/siltstone showing evenly parallel to undulate lamination. Scour-and-fill features are isolated in predominantly tabular deposits composed of mudstones interbedded with fine to medium-grained sandstones showing planar to slightly undulate lamination. Silicified plant remains previously classified as belonging to the Psaronius genus found in the uppermost levels of the Pedra de Fogo Formation, near the contact with the Motuca Formation, are considered here as excellent biostratigraphic markers. Fish remains, ostracods, bryozoans and scolecodonts represent other fossils that are present in the succession. Mudflat deposits developed in an arid and hot climate probably in the Early Permian. Semi-arid conditions prevailed in the Middle Permian allowing the proliferation of fauna and flora in adjacent humid regions and onto the lake margin. The climate variation was responsible for the contraction and expansion phases of the lake, fed by sporadic sheet floods carrying plant remains. The reestablishment of the arid climate, at the end of Permian, marks the final sedimentation of the Pedra de Fogo Formation, linked to the consolidation of the Pangaea Supercontinent. This last event was concomitant with the deposition of the Motuca Formation red beds and the development of extensive ergs related to the Triassic Sambaíba Formation in Western Gondwana.
\end{abstract}

(c) 2016 Elsevier Ltd. All rights reserved.

\footnotetext{
* Corresponding author. R. Augusto Corrêa, 01, Belém, PA 66075-110, Brazil. E-mail addresses: raphaelneto@ufpa.br, raphael.araujo@cprm.gov.br (R.N. Araújo), anogueira@ufpa.br (A.C.R. Nogueira), jbandeira@ufpa.br
} (J. Bandeira), angelica@ufpa.br (R.S. Angélica).

\section{Introduction}

The Permian Period is characterized by global climate changes and near its boundary with the Triassic Period there are records of the biggest extinction event that killed $97 \%$ of all species on Earth 
(Koeberl et al., 2004; Kiehl and Shields, 2005; Meyer et al., 2008). At the end of the Permian Period, hot and dry conditions prevailed everywhere on Pangaea, and deserts became widespread in several parts of West Gondwana (Scotese et al., 1999; Zharkov and Chumakov, 2001). In South America, climatic changes were associated with tectonic uplift triggered by the Gondwanide Orogeny causing environmental changes within the continent (Caputo, 1984; Zalán, 1991). Uplift of the continental area caused the confining of seas and the development of large lake systems (Scotese et al., 1999). One of the most complete records of the Permian Period in Brazil is the Pedra de Fogo Formation, which is predominantly composed of fine to coarse-grained sandstones, mudstones and subordinately, silicified carbonates and evaporites exposed in an east-west strip in the central part of the Parnaíba Basin. Silex is abundant in Pedra de Fogo deposits, frequently called the "Silex Formation" (Plummer, 1946). Well-preserved and silicified Permian flora have been described by several authors (Coimbra and Mussa, 1984; Mussa and Coimbra, 1987; Martins, 2000; Rößler and Galtier, 2002a, 2002b, 2003; Kurzawe et al., 2013; Tavares et al., 2014).

The Parnaíba Basin is located on the South American platform, in the northeastern portion of Parnaíba Province (Góes, 1995) and covers an area of $600,000 \mathrm{~km}^{2}$ in northern Brazil. The boundaries of the Parnaíba Basin are the Araguaia Belt to the west, the Ferrer Urbano Santos Arch, to the north, the Brasilia Fold Belt to the south and the Borborema Province to the east, which is considered to form the basement of the basin. Igneous, metamorphic and sedimentary rocks, with ages ranging from Archean to Ordovician, form the basement where Cambrian-Ordovician precursor grabens were developed (Góes, 1995; Vaz et al., 2007). The lithostratigraphic framework of the Parnaíba Basin has been modified from Small (1914) and was included in different stratigraphic proposals (Góes and Feijó, 1994; Vaz et al., 2007).

The paleoenvironment of the Pedra de Fogo Formation has been interpreted focusing on lithostratigraphic aspects and only in the last decade, this unit was studied using facies analysis (Andrade et al., 2014). In addition, the discontinuous exposures of this unit extending over hundreds of kilometers along the basin make it difficult for continuous stratigraphic correlations. Another problematic issue is the lack of appropriate material in order to determine ages by palynology. Gray to black mudstone is rare in the outcrops and the succession is generally reddish indicating intense oxidization of the lithotypes. Body fossils are scarce, restricted to some intervals and mostly without biostratigraphic significance. In this study, the revisited tentative type section of the Pedra de Fogo Formation is integrated into a new facies framework based on the reinterpretation of well-known outcrops of the western and eastern borders of the Parnaiba Basin. The Pedra de Fogo Formation represents a climate-induced shallow lacustrine system with retreat and expansion phases that influenced not only the sedimentation pattern, but also the fossilization processes responsible for the preservation of the Permian fauna and flora in Western Gondwana.

\section{Study area and methods}

Outcrop-based facies and stratigraphic analysis of the Permian deposits were carried out along the eastern and western borders of the Parnaíba Basin. The observations were concentrated on the best exposures of these deposits near Pastos Bons and Nova Iorque Cities, State of Maranhão (MA), and in Araguaína and Filadélfia Cities, State of Tocantins (TO), northern Brazil (Fig. 1). In this study, we analyzed the type section of this unit, exposed along the banks of the Pedra de Fogo River, Nova Iorque Region, and integrated it into a new stratigraphic framework. We present a comprehensive facies analysis of three composite stratigraphic sections. Facies analysis involved facies associations (consisting of groups of facies genetically related to one another) which have some environmental significance (Collinson, 1969; Walker, 1992, 2006; Reading and Levell, 1996). The facies description follows the code proposed by Miall (1977), where the first capital letter indicates the main lithology and the second letter represents the main structure of the rock. The cross-bedding sets followed the Mckee and Weir (1953) classification: small (sets less than $0.3 \mathrm{~m}$ in height), medium (sets $0.3-3 \mathrm{~m}$ long) and large (sets over $3 \mathrm{~m}$ in height). Systematic samples were collected from specific beds.

$\mathrm{X}$-ray diffraction (XRD) and scanning electron microscopy (SEM) were used as auxiliary techniques on the petrography of the sandstones, mainly to identify evaporitic minerals and their possible replacements. SEM analysis allowed the acquisition of microphotography of small e fossilized bodies described in the studied succession. In addition, thin sections of carbonate rocks were stained with Alizarin-Red S in order to distinguish calcite from dolomite, as proposed by Adams et al. (1984).

\section{Previous work}

The Balsas Group consists of clastic-evaporitic rocks that overlie the Canindé Group and is unconformably overlain by the Mosquito, Grajaú, Codó, Itapecuru and Urucuia formations as well as the Mearim Group (Góes and Feijó, 1994). The Balsas Group includes the Piauí, Pedra de Fogo, Motuca and Sambaíba formations (Vaz et al., 2007). The Pedra de Fogo Formation (Plummer, 1946) refers to a succession of sandstones, shales, limestones and mainly silex containing fossilized wood, with its type section being named after the homonymous river, between the Municipalities of Pastos Bons and Nova Iorque, State of Maranhão, Brazil. The unit occurs in the central part of the Parnaiba Basin where it extend for more than $600 \mathrm{~km}$ along an $\mathrm{E}-\mathrm{W}$ trend and reaches thicknesses up to $189 \mathrm{~m}$ as determined by sub-surface investigations (Faria Jr. and Truckenbrodt, 1980a; Vaz et al., 2007).

Faria Jr. (1979) divided the Pedra de Fogo Formation in to the Silex Basal, Middle and Upper or "Trisidela" members. Lima and Leite (1978), Faria Jr. and Truckenbrodt (1980b), Mussa and Coimbra (1987) and Góes and Feijó (1994) placed this unit in the Early-Middle Permian, while Cox and Hutchinson (1991) consider a Late Permian age. Dino et al. (2002) have attributed a Late Permian age to the upper part of the Pedra de Fogo Formation based on correlations with palynozones of the Amazon Basin. The unit overlies the Piauí Formation, of Carboniferous age, interpreted as fluvial and aeolian deposits, with small-scale short-termed transgression records according to Caputo (1984), and Lima and Leite (1978). Red bed lake sediments from the Late Permian Motuca Formation and aeolian deposits from the Triassic Sambaíba Formation gradually overlie the Pedra de Fogo Formation in the western Parnaiba Basin (Abrantes and Nogueira, 2013).

The Pedra de Fogo Formation has been interpreted predominantly as transitional fluvio-deltaic deposits (Barbosa and Gomes, 1957; Oliveira, 1961; Moore, 1964; Aguiar, 1964; Cunha, 1964; Northfleet, 1965; Ojeda and Bembom, 1966; Ojeda and Perillo, 1967; Lima and Leite, 1978; Faria Jr. and Truckenbrodt, 1980a; Faria Jr. and Truckenbrodt, 1980b; Coimbra and Mussa, 1984; Caldas et al., 1989). Faria Jr. (1979) interpreted it as an epicontinental shallow marine setting and Góes and Feijó (1994) inferred a shallow neritic to storm-influenced coastal environment associated with sabkha plains. Dino et al. (2002) based on lithological data, the presence of Psaronius, abundance of continental palynomorphs and scarcity of marine microplanktons, attributed it to a shallow marine to coastal environment under an arid to semiarid climate. 

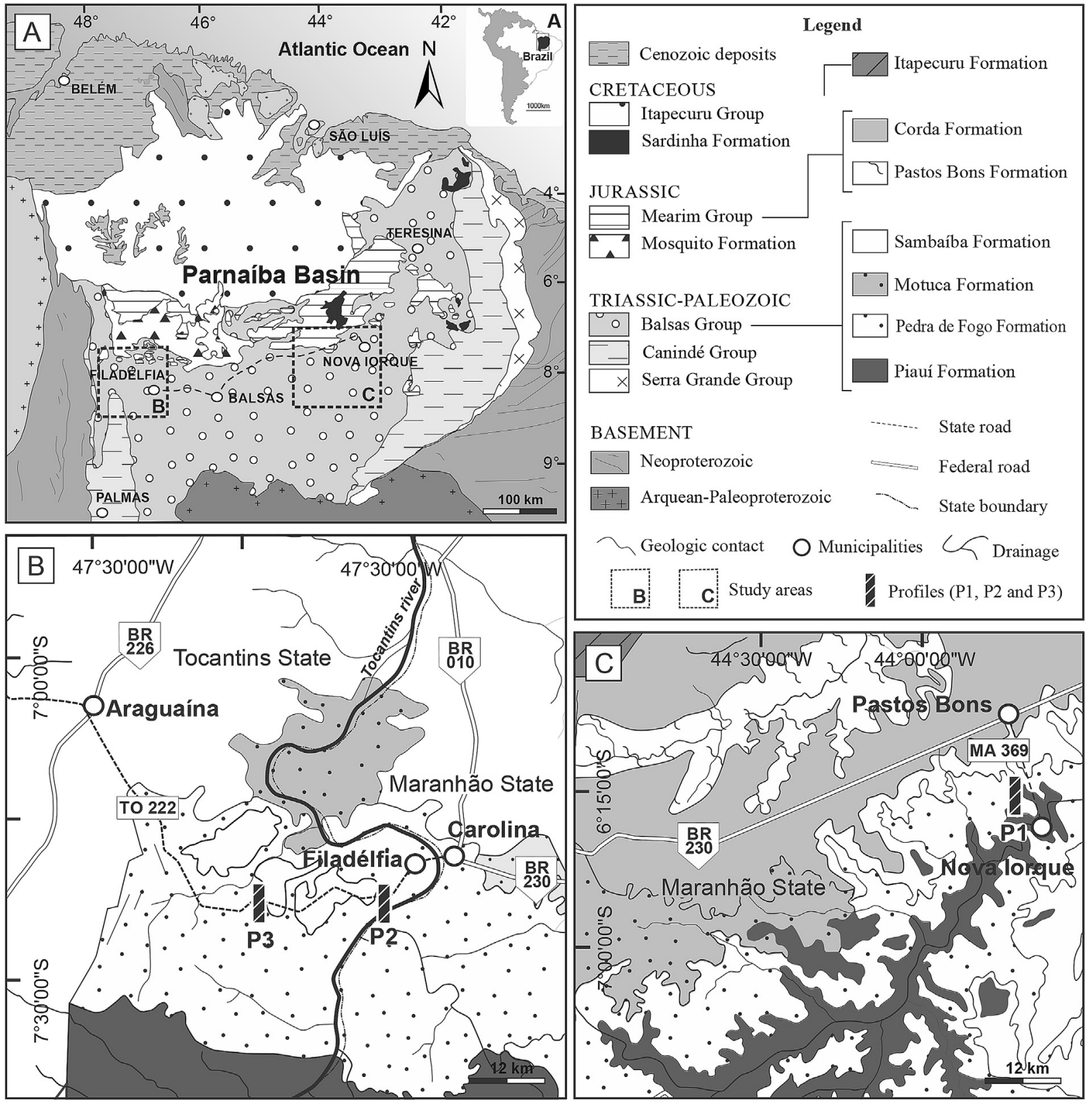

Fig. 1. Location map of the study areas at the western and eastern borders of the Parnaíba Basin. Modified from Aguiar and Nahass (1969).

\section{Results}

\subsection{The Pedra de Fogo Formation along the eastern and western borders of the Parnaíba Basin}

\subsubsection{General aspects}

The best exposures of the Pedra de Fogo Formation are residual hills and outcrops along roadcuts in the Araguaína-Filadélfia region, Tocantins State and in the Pastos Bons-Nova Iorque region, Maranhão State, northern Brazil. The Motuca and Sambaíba formations unconformably overlie the upper part of the Pedra de Fogo Formation at the western border of the Parnaíba Basin. Along the eastern border, Cretaceous rocks from the Pastos Bons Formation unconformably overlie the Pedra de Fogo Formation (Fig. 2). Pebbly sandstones with abundant silex fragments, considered here as reflecting a reworking process of the Pedra de Fogo Formation, mark the upper contact with the Pastos Bons Formation, of
Cretaceous age (Profile 3, Fig. 3). On both borders of the Parnaíba Basin, the Pedra de Fogo Formation overlies the Carboniferous Piauí Formation.

A $20 \mathrm{~m}$ thick siliciclastic succession from the Pedra de Fogo Formation occurs along the Pedra de Fogo River in the Pastos BonsNova Iorque region, and has been considered as the type section (Profile 1, Fig. 3). However, in the region of Filadélfia-Araguaína, the exposed succession is $40 \mathrm{~m}$ thick and we considered it to be a complementary section of the unit (Profiles 2 and 3, Fig. 3). Eleven sedimentary facies were defined in this study (Table 1 ) and they are grouped into three facies associations (FA) shown in Table 2. FA1 is interpreted as mudflat deposits while FA2 consists of nearshore sediments and FA3 represents wadis/inundites deposits. In the Araguaína-Filadélfia region, there are records of FA1, FA2 and FA3 deposits in the upper part of the Pedra de Fogo Formation, while AF1 deposits characterize the lower part of the unit.

The Pedra de Fogo succession comprises mainly fine to medium- 


\begin{tabular}{|c|c|c|c|c|c|}
\hline Fm. & AGE & LITHOSTRATIGRAPHY & PROFILES & DESCRIPTION & $\begin{array}{l}\text { SEDIMENTARY } \\
\text { ENVIRONMENT }\end{array}$ \\
\hline
\end{tabular}

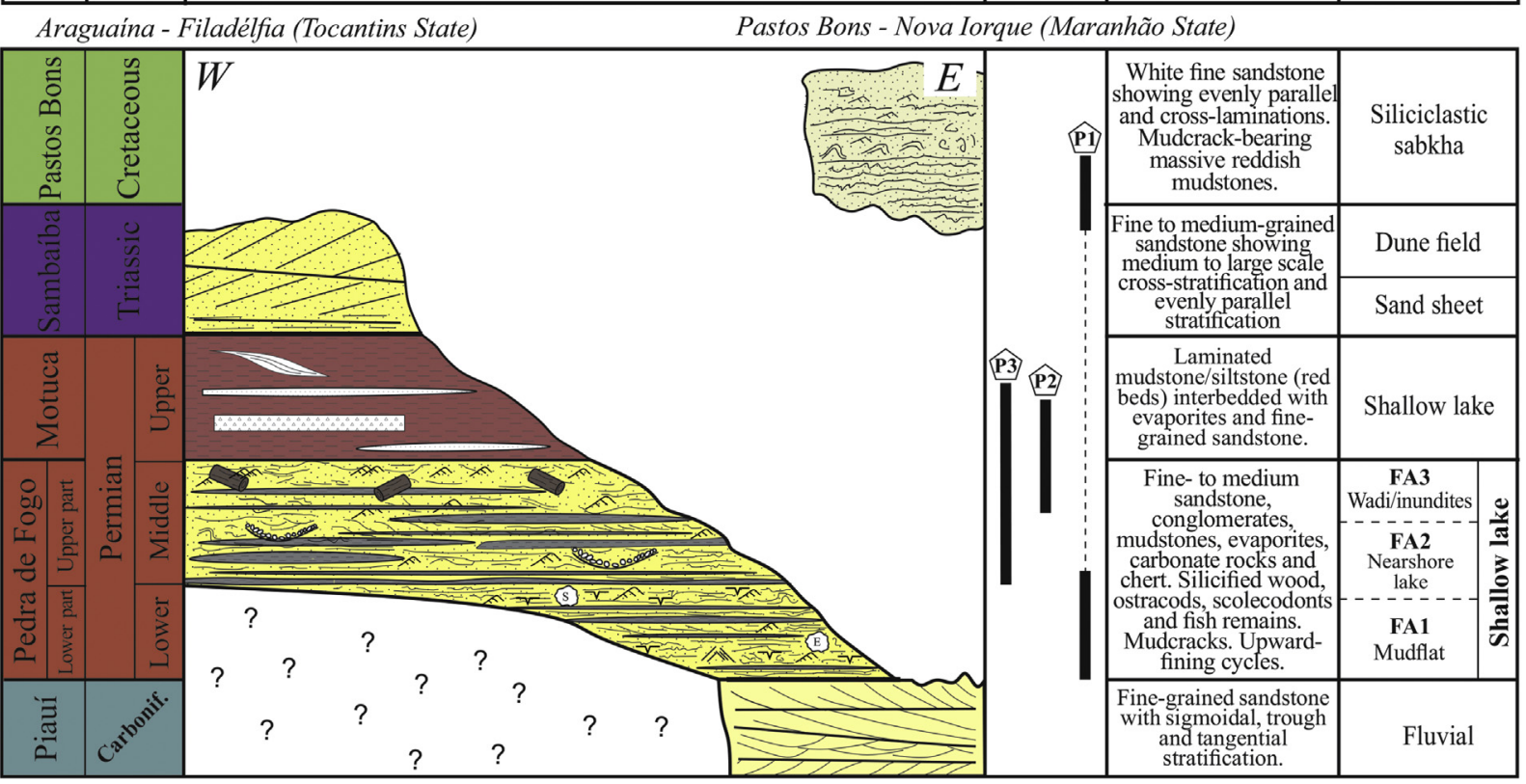

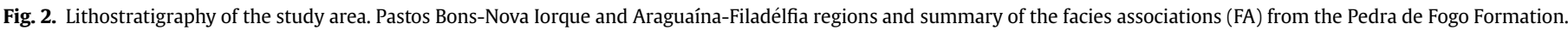

grained sandstones interbedded with mudstones organized in to metric-scale cycles that get finer and coarser upwards. Silex, conglomerates, evaporites and carbonates occur subordinately. Carbonate and silica are the main cement of sandstones showing reddish, greyish and whitish colors.

\subsubsection{Facies association (FA)}

4.1.2.1. Mudflat deposits (FA1). FA1 occurs in the Pastos Bons-Nova Iorque and Araguaína-Filadélfia regions. It is approximately $10 \mathrm{~m}$ thick and consists of flat bodies continuously exposed for dozens of kilometers generally arranged in metric scale cycles that coarsen upward (Profile 1 and 3, Fig. 3). This association commonly consists of silicified, fine-grained sandstones alternated with carbonate cement and layers of massive silex, mudstones, siltstones and reddish dolostone. Mudstone and siltstone are the main lithotypes of FA1, generally exhibiting evenly parallel to undulate lamination (MSl). Other facies are represented by sandstone/mudstone showing desiccation cracks (SPd), fine-grained sandstone showing climbing ripple cross-lamination (Sc), silicified evaporitic nodules (Sn) and megaripple bedding ( $\mathrm{Sr}$ ), as well as medium-grained sandstone with massive bedding ( $\mathrm{Sm}$ ) and red laminated dolomudstone (Dl) (Fig. 4A-D). Silicified tepees, silcretes and desiccation cracks that occur at the top of the cycles indicate a shallowingupward tendency (Figs. 4G and 5C, D). Nodules and silicified evaporites casts similar to popcorn and cauliflower features that form a crust are generally found associated with the upper part of the cycles (Fig. 5A and B). Desiccation cracks are mainly polygonal in shape and, sometimes, form deep cracks or synsedimentary dykes filled with fine-grained sand, rarely calcite-cemented. Irregular and wrinkled laminations associated with silicified nodules possibly reflect stromatolites. Pebbly sandstone with abundant silex fragments marks the contact with the Pastos Bons Formation, of Cretaceous age (Fig. 3, profile 1; Fig. 4E and F).

The FA1 represents a mudflat setting, characterized by high levels of alkalinity and salinity associated with high evaporation rates and a negative water balance (Amiel and Friedman, 1971; Briere, 2000). Sabkhas or mudflats are extensive regions influenced by evaporitic and siliciclastic sedimentation, typical of saline lakes (Talbot and Allen, 1996). The occurrence of desiccation cracks, tepees and evaporites in a mudflat region involves essentially subaerial exposure, where periodic groundwater resurgence commonly occurs (Kendall and Warren, 1987; Kendall, 1992). Tepees result from synsedimentary cementation and expansion of carbonate and/or evaporitic surface layers under a high evaporation rate. Flash flood events or long subaerial exposures interrupted this process, causing extensive and multiple cracking phases (Kendall, 1992).

Evaporation promotes the rise of the groundwater level and percolation of alkaline fluids in the vadose zone (Demicco and Hardie, 1994; Tucker, 2003). In contrast, the accommodation space for fine sedimentation increases during periods in which the lake water level rises, favoring clastic-evaporitic sedimentation whose record is preserved at the top of shallowing-upward cycles (Lowenstein and Hardie, 1985). The halite identified by x-ray diffraction probably indicates primary evaporite precipitation in a supersaturated environment (Fig. 6). Silicified evaporite casts (popcorn and cauliflower-like features) possibly indicate crusts replaced by silica in a mesodiagenetic stage. Evaporitic crusts result from the evaporation of groundwater within the capillary fringe (Kendall, 1992). The precipitation of evaporites is linked to a hot and arid climate, high rate of evaporation of surficial water and low levels of humidity (Talbot and Allen, 1996; Kendall, 1992).

Carbonate rocks are rare in the Pedra de Fogo Formation. The dolostone found in FA1 resulted from eodiagenetic to mesodiagenetic dolomitization triggered by similar seepage mechanisms (Figueiras and Martins, 1985). In the same way, pedogenetic processes or replacement of evaporite minerals in an arid to semiarid climate generated the rare horizons of silcrete (cf. Summerfield, 1983; Thiry, 1999).

4.1.2.2. Nearshore setting (FA2). FA2 occurs in the Araguaína-Filadelfia region as tabular bodies, approximately $30 \mathrm{~m}$ thick, continuously exposed over hundreds of kilometers, generally arranged in coarsening-upward cycles of metric size (Fig. 7B). In the western 


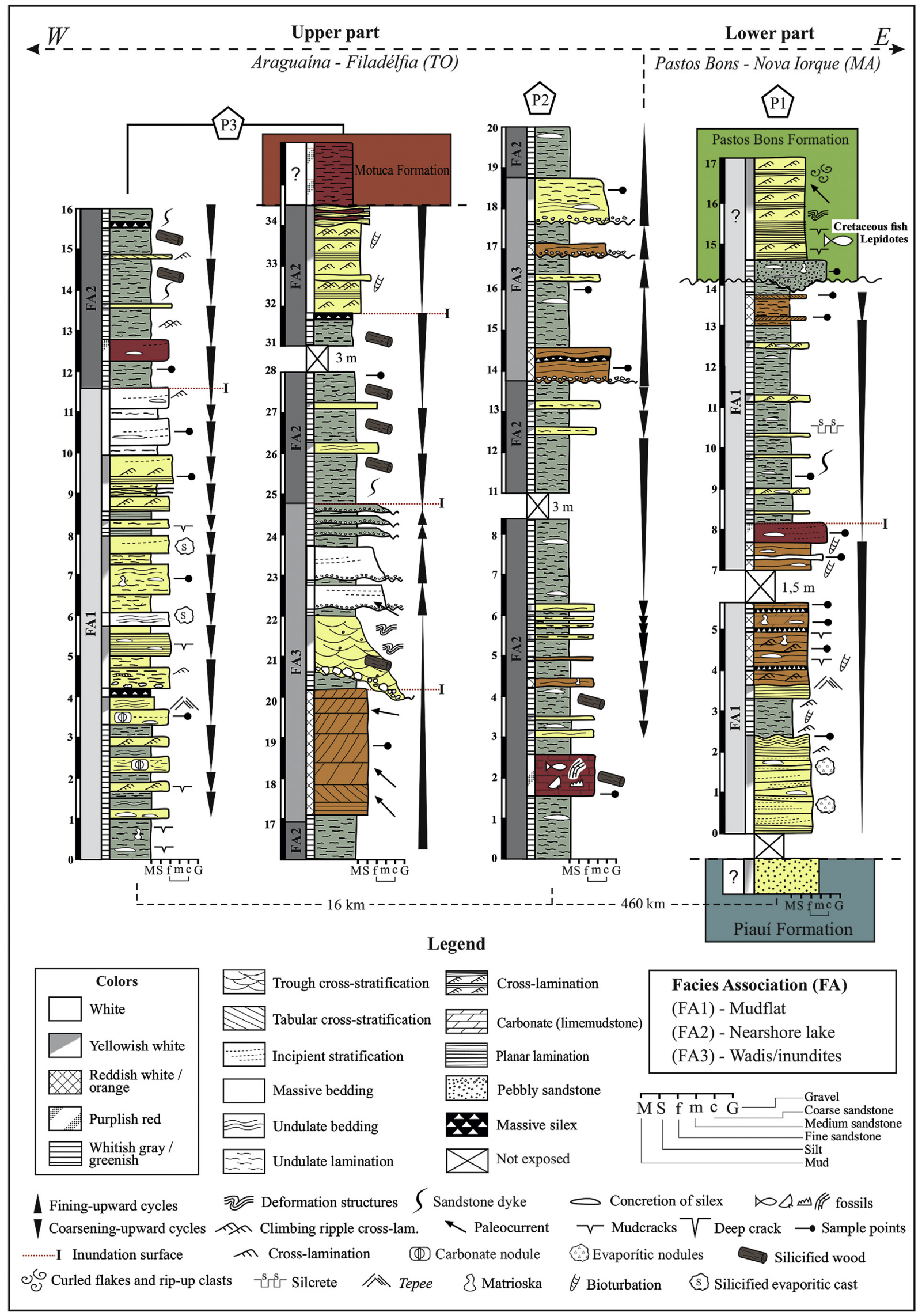

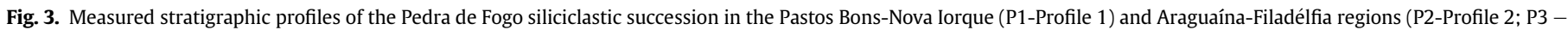
Profile 3). 
Table 1

Summary of the facies and sedimentary processes of the Pedra de Fogo Formation.

\begin{tabular}{|c|c|c|}
\hline Facies & Description & Sedimentary process \\
\hline $\begin{array}{l}\text { Mudstone/siltstone showing } \\
\text { evenly parallel to undulate } \\
\text { lamination (MSl) }\end{array}$ & $\begin{array}{l}\text { Flat to undulate tabular layers. Evenly parallel to undulated } \\
\text { lamination. Silicified wood in situ, ostracods, scolecodonts and fish } \\
\text { teeth. }\end{array}$ & $\begin{array}{l}\text { Deposition by suspension in low- energy environment. Proliferation } \\
\text { of plants in continental setting and arthropods worms and fish in } \\
\text { brackish to saline waters. Silicification of plant material during the } \\
\text { deposition and/or eodiagenetic stage. }\end{array}$ \\
\hline $\begin{array}{r}\text { Sandstone/mudstone with } \\
\text { desiccation cracks (SPd) }\end{array}$ & $\begin{array}{l}\text { Tabular layers. Orthogonal and complete desiccation cracks and } \\
\text { subordinately deep cracks. }\end{array}$ & $\begin{array}{l}\text { Deposition by suspension in low-energy environment associated } \\
\text { with subaerial exposure intervals. }\end{array}$ \\
\hline $\begin{array}{l}\text { Sandstone showing climbing } \\
\text { ripple-cross lamination } \\
\text { (Sc) }\end{array}$ & $\begin{array}{l}\text { Flat to undulate tabular layers. Fine-grained sandstone showing } \\
\text { supercritical and/or subcritical climbing ripple-cross lamination. }\end{array}$ & $\begin{array}{l}\text { Deposition in lower flow bedload transport regime and high rates of } \\
\text { suspended load fallout. }\end{array}$ \\
\hline $\begin{array}{l}\text { Sandstone showing evenly } \\
\text { parallel lamination (Sp). }\end{array}$ & $\begin{array}{l}\text { Tabular layers. Fine to medium-grained sandstone showing evenly } \\
\text { parallel lamination. Subordinate low angle cross- lamination. }\end{array}$ & Deposition in upper flow-regime (flat bed). \\
\hline $\begin{array}{l}\text { Sandstone showing nodular } \\
\text { halite and silicified } \\
\text { evaporites (Sn) }\end{array}$ & $\begin{array}{l}\text { Tabular layers. Fine-grained sandstone showing nodules of halite } \\
\text { and silicified evaporitic cast similar to a "popcorn" texture. } \\
\text { Subordinate small-scale load-cast. }\end{array}$ & $\begin{array}{l}\text { High saturation and precipitation of evaporites. Gravitational } \\
\text { instability and liquefaction process. }\end{array}$ \\
\hline Massive sandstone (Sm) & $\begin{array}{l}\text { Tabular beds showing an irregular, sharp and erosional base. } \\
\text { Medium-grained sandstone showing massive bedding and } \\
\text { sometimes inverse grading. }\end{array}$ & $\begin{array}{l}\text { Liquefaction, high rate of sediment influx and gravitational } \\
\text { instability, rapid deposition. }\end{array}$ \\
\hline $\begin{array}{l}\text { Massive pebbly sandstone } \\
\quad(\mathrm{Pm})\end{array}$ & $\begin{array}{l}\text { Tabular layers. Medium-grained and pebbly sandstone showing } \\
\text { massive bedding. The polimitic pebbles occur sparsely disseminated } \\
\text { in the matrix. }\end{array}$ & Rapid deposition or liquefaction process. \\
\hline $\begin{array}{l}\text { Sandstone with megaripple } \\
\text { bedding }(\mathrm{Sr})\end{array}$ & $\begin{array}{l}\text { Flat to undulate tabular layers. Fine to medium-grained sandstone } \\
\text { showing megaripple bedding. Bedforms preserved by mud drapes. }\end{array}$ & $\begin{array}{l}\text { Migration of megaripples under lower flow-regime and high rates of } \\
\text { suspended load fallout. }\end{array}$ \\
\hline $\begin{array}{l}\text { Sandstone showing tabular } \\
\text { cross-stratification (St) }\end{array}$ & $\begin{array}{l}\text { Tabular layers. Fine to medium-grained sandstone. Small scale } \\
\text { tabular cross- stratification. Subordinately, discontinuous mud } \\
\text { draped-mantled forests. Paleocurrents flow towards E-SE. }\end{array}$ & $\begin{array}{l}\text { Migration of megaripples under the action of a unidirectional flow in } \\
\text { a lower flow-regime sporadically alternating with suspension load } \\
\text { fallout. }\end{array}$ \\
\hline $\begin{array}{l}\text { Sandstone/conglomerate } \\
\text { with trough cross- } \\
\text { stratification (SCt) }\end{array}$ & $\begin{array}{l}\text { Lenticular beds of coarse-grained sandstone/conglomerate showing } \\
\text { a scoured base. Subordinate silicified wood. }\end{array}$ & $\begin{array}{l}\text { Migration of 3D megaripple in lower flow-regime. Transport of stems } \\
\text { in suspension (floating) parallel to the flow. }\end{array}$ \\
\hline $\begin{array}{l}\text { Laminated dolomudstone } \\
\text { (Dl) }\end{array}$ & $\begin{array}{l}\text { Tabular beds of laminated dolomudstone. The rock is red in color (red } \\
\text { bed) and the parallel lamination becomes laterally gently undulate. } \\
\text { Rare silt grains. }\end{array}$ & $\begin{array}{l}\text { Chemical precipitation of carbonate. Subordinate deposition from } \\
\text { suspension. }\end{array}$ \\
\hline
\end{tabular}

Table 2

Description and geometry/architectural elements of facies associations of the Pedra de Fogo Formation.

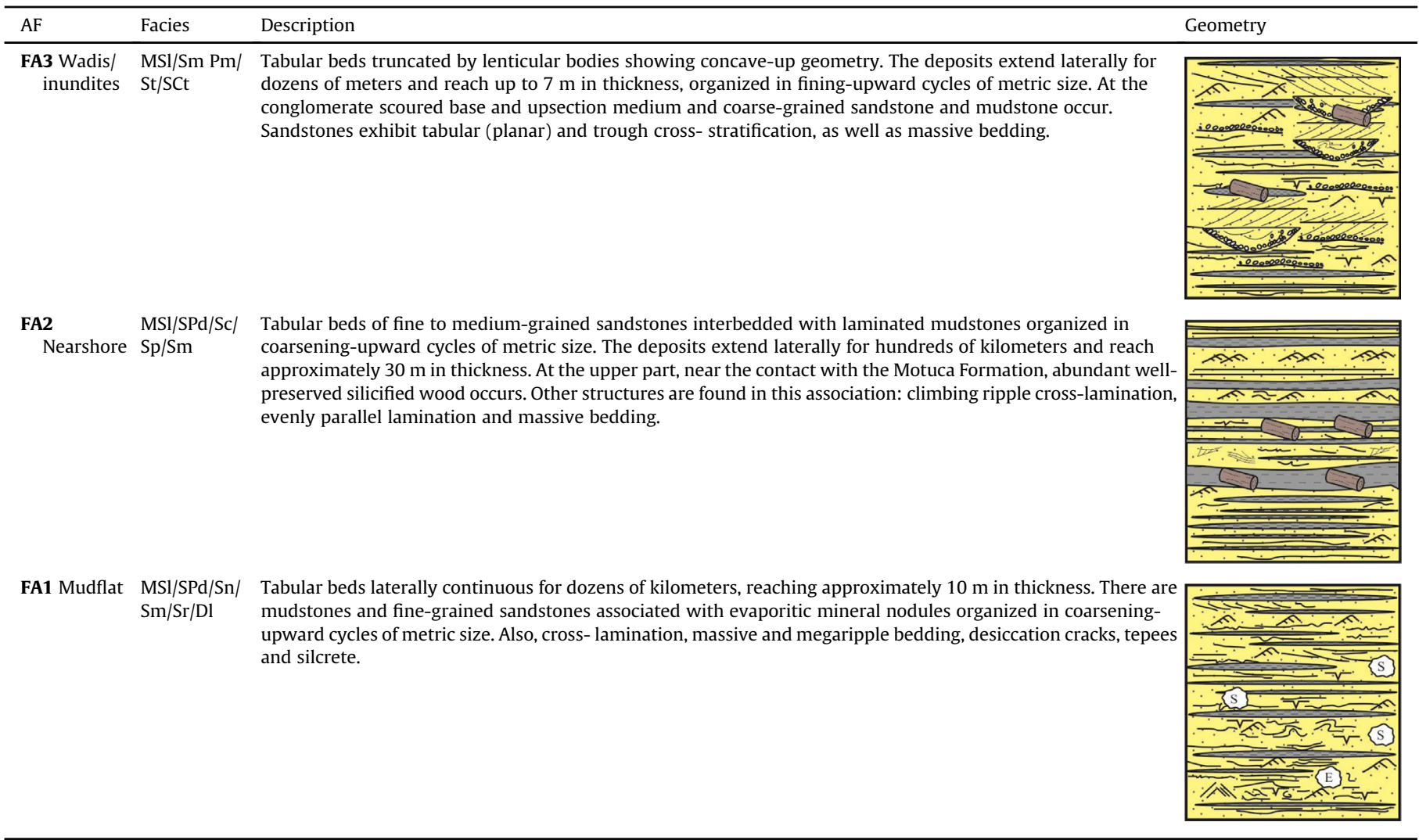



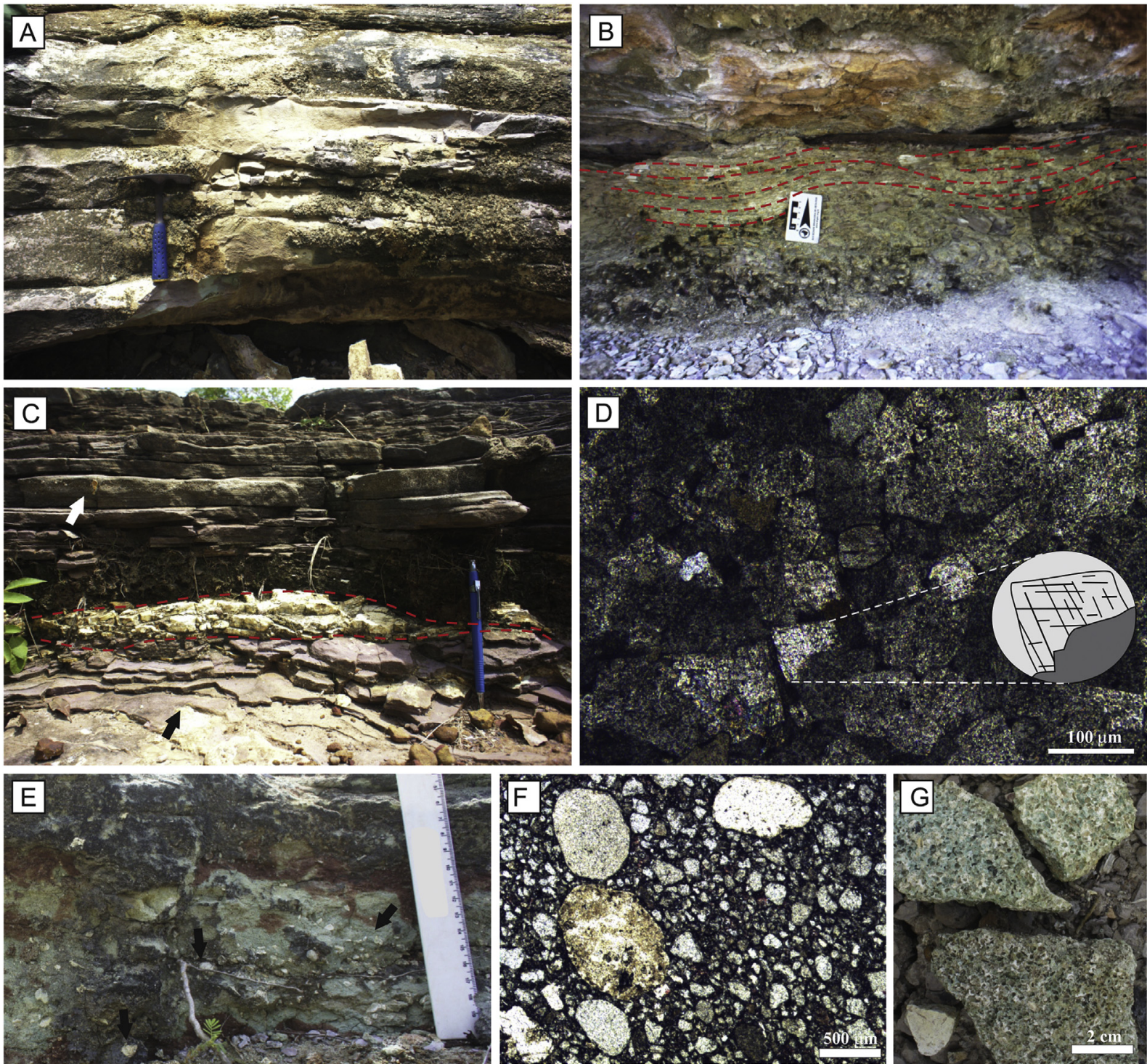

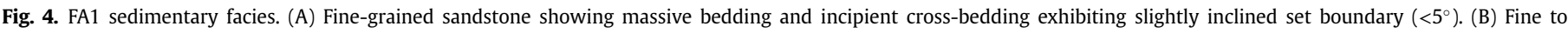

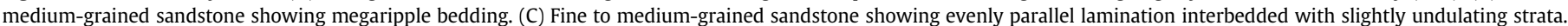

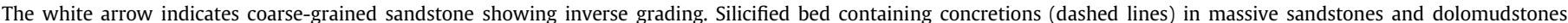

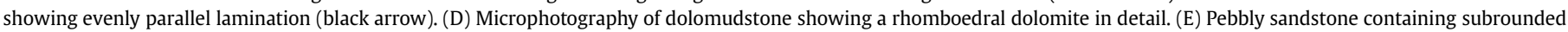
silex pebbles (arrows) at the base of the Pastos Bons Formation. (F) Microscopic image of silex pebbles from the Pastos Bons Formation. (G) Samples of silcrete.

portion of the Parnaiba Basin, red beds from the Motuca Formation conformably overlie this association while an extensive thickening of reddish mudstones towards the top at the contact zone, suggests a transitional tendency (Fig. 7A). In this facies association, it is common for silica to form oblate concretions and concentric growth shapes similar to cookies, called "silex cookies" byFaria Jr. (1979), and asymmetric concretions similar to matryoshka dolls (Fig. 7F). FA2 is interpreted as nearshore deposits and consists of fine to medium-grained sandstone with evenly parallel lamination $(\mathrm{Sp})$, medium-grained sandstone showing massive bedding $(\mathrm{Sm})$, plane-parallel laminated mudstone/siltstone (MSl), climbing ripple cross-laminated, fine sandstone (Sc) and sandstone/mudstone showing desiccation cracks (SPd) (Fig. 7B-E). The fossiliferous assembly of FA2 consists of silicified wood, fish remains, ostracods, bryozoans and scolecodonts (Fig. 8).

The marginal areas of the Pedra de Fogo Lake were recurrently exposed for long periods, generating intervals with desiccation cracks and deepcracks (Fig. 7E). However, during periods of increasing water depth, high-energy currents or sheet flow and locally reworked silex granules formed pebbly sands. The rapid sedimentation of sands or the intense bioturbation generated massive beds. Migration of small-scale ripple marks with high rates of suspended load fallout and subordinate bedload transport was common in the nearshore zone (Fig. 7C and D). Thick layers of laminated shales in this association confirm high rates of suspended load sporadically interrupted by terrigenous inflow forming coarsening-upward cycles. The siliciclastic inflow is provided by rivers with bedload concentrated near the river mouths (cf. Talbot and Allen, 1996).

Silicified plant remains, preliminary classified as Psaronius have been interpreted as having been positioned in situ and are used to indicate the presence of a petrified forest. Psaronius found in their life position (in situ) in Tocantins State, northeastern Brazil, have also been used as evidence to identify the boundaries of a petrified 

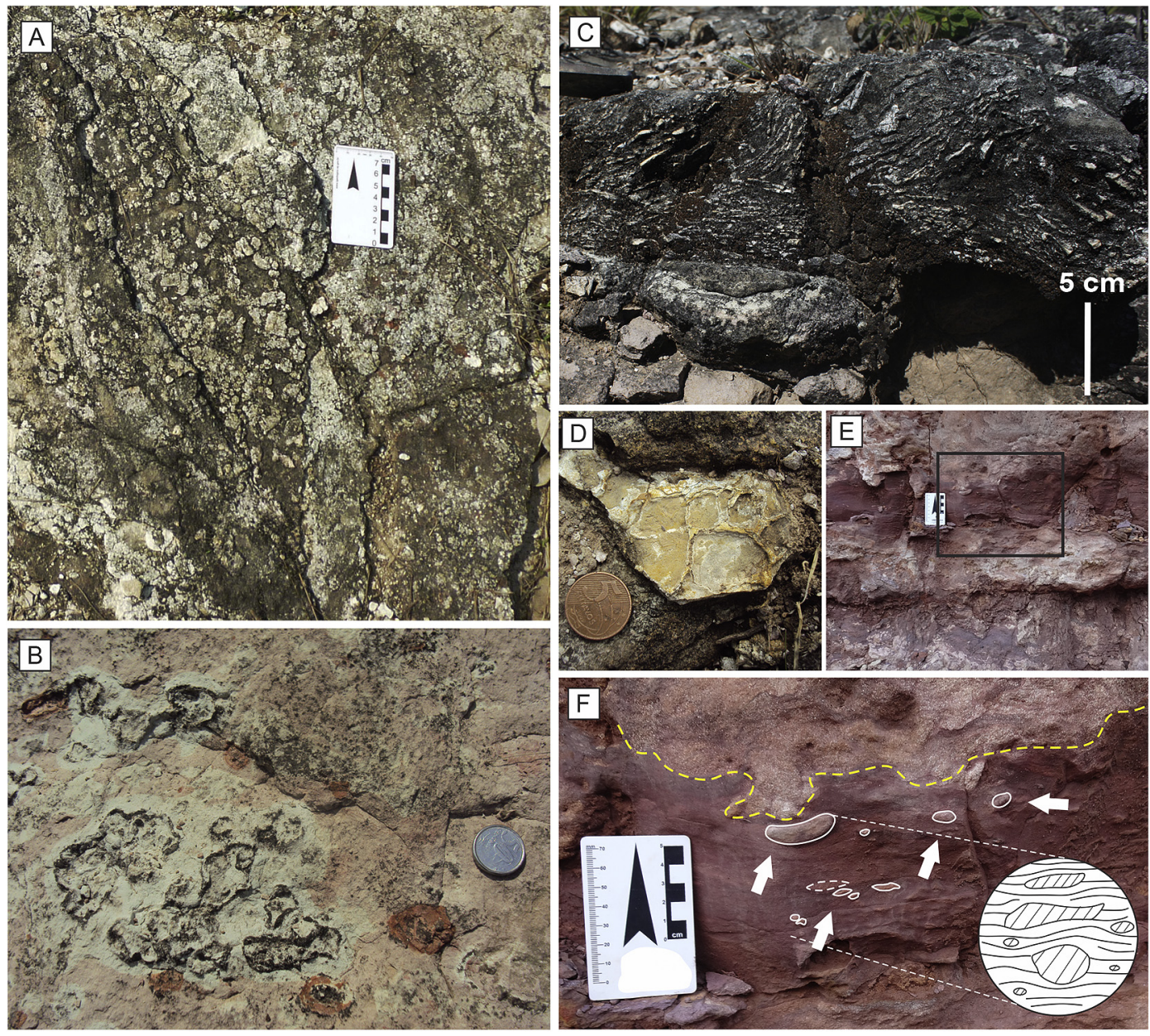

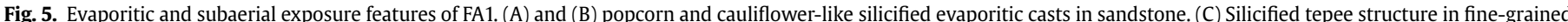

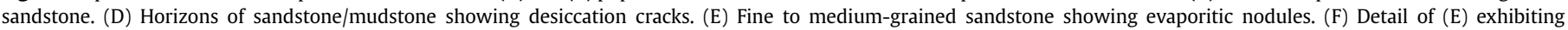
evaporitic concretions (arrows). Note the coarse-grained sandstone load cast sinking in fine-grained sandstone.

forest (Dias-Brito et al., 2007). Within the study areas, all fossilized plant material is allochthonous, which is indicated by their subhorizontal position in the strata, suggesting an equilibrium state of the trunks during transportation. In a context that opposes Capretz and Rohn (2013), our stratigraphic framework strongly indicates that fossilized plant material occurs exclusively in the upper Pedra de Fogo Formation and not in the Motuca Formation (Fig. 8A and B). The fossilized wood occurs in fine to medium-grained sandstone and shales in FA2 and locally in the lags of inundite/wadi FA3 deposits. The post-mortem stage indicates transport of wood fragments by high energy (ephemerous?) rivers or sheet flood transporting different kinds of fragments and with different

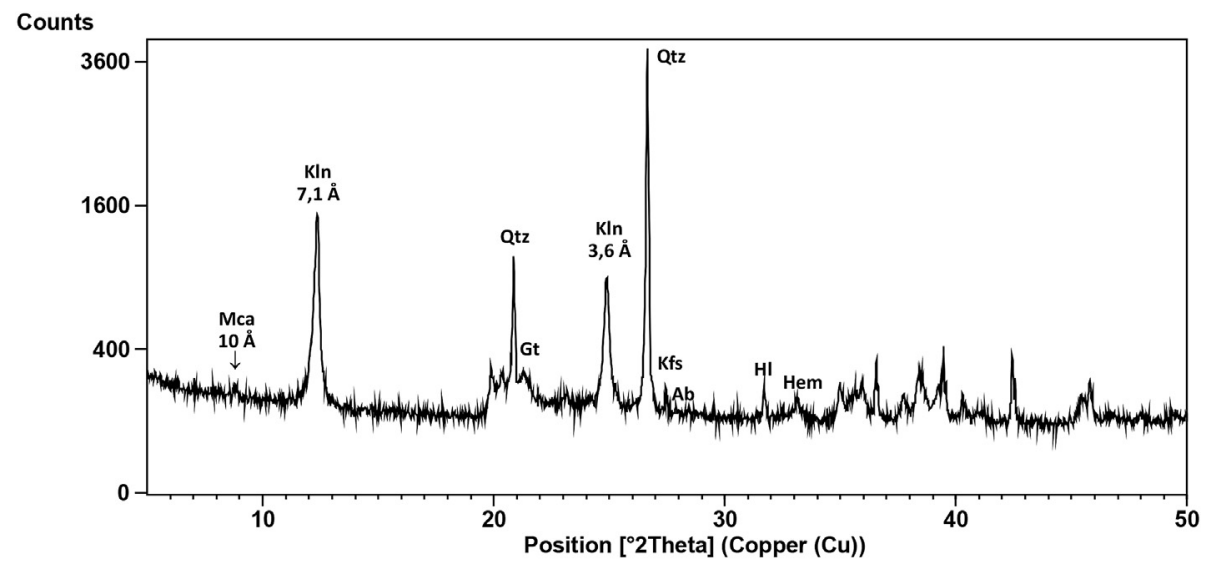

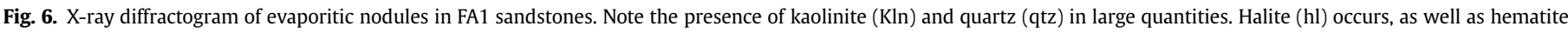
(Hem), K-feldspar (Kfs) and possibly goethite (Gt). Mica and albite (Ab) occur in very small quantities. 

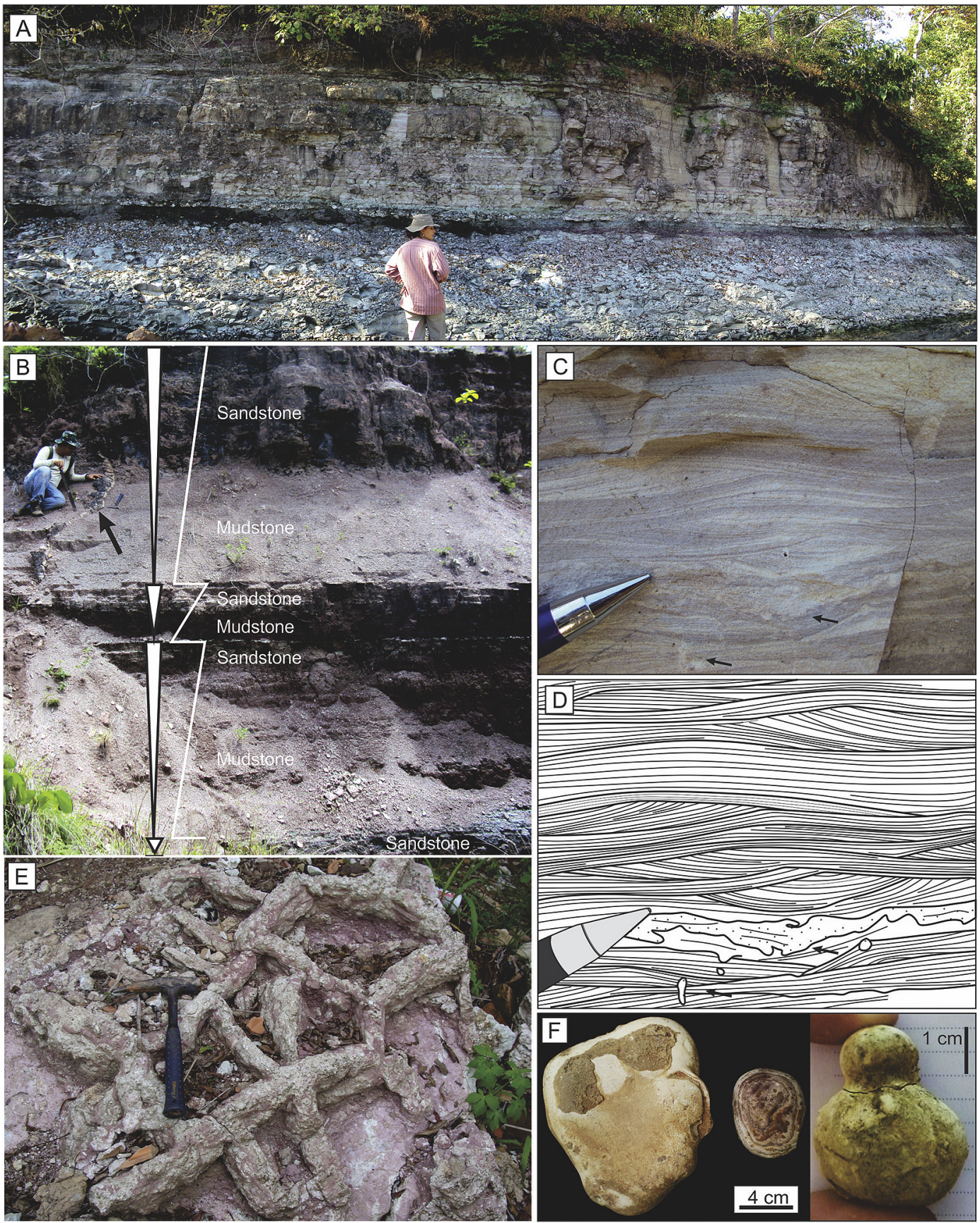

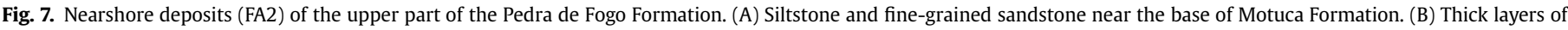

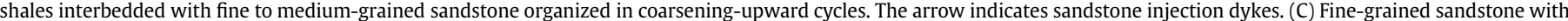

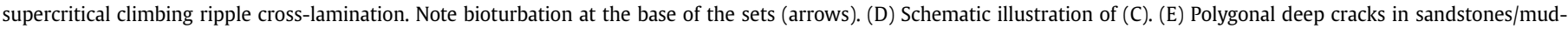
stones. (F) Different forms of silica concretions: oblate form showing a concentric growth similar to cookies and asymmetric growth similar to Russian matryoshka dolls.

decompositional states, explaining the diversity found in the fossiliferous sites. During transport, the floating fragments passed to the nearshore zone until the distal part of the lake, and the weight of the water-soaked wood favored its sinking to the lake bottom in a subhorizontal position, being rapidly buried by mud and sands. Silica-saturated water favored rapid fossilization over complete wood decomposition, explaining the well-preserved plant material currently found in the upper Pedra de Fogo Formation.

Fish teeth and scales are also found in the upper Pedra de Fogo Formation, as well as ostracods, bryozoans and scolecodonts. We did not perform a detailed classification of the taxonomy on the genera, but the presence of these individuals confirms the paleoenvironmental interpretation proposed for the unit. The bryozoans are sessile and are found encrusted in any aquatic sediment. Even though they prevail in salt water, bryozoans can also occur in fresh water (Taylor, 2005). Bryozoans and scolecodonts, which are fossilized jaws of the polychaetes, were recorded only in thin sections and generally attest to the presence of a low-energy marine paleoenvironment (Traverse, 2007). Ostracods are essentially aquatic and live in freshwater, brackish, marine, supersaline or other types of environments, including forest soils and even in the 

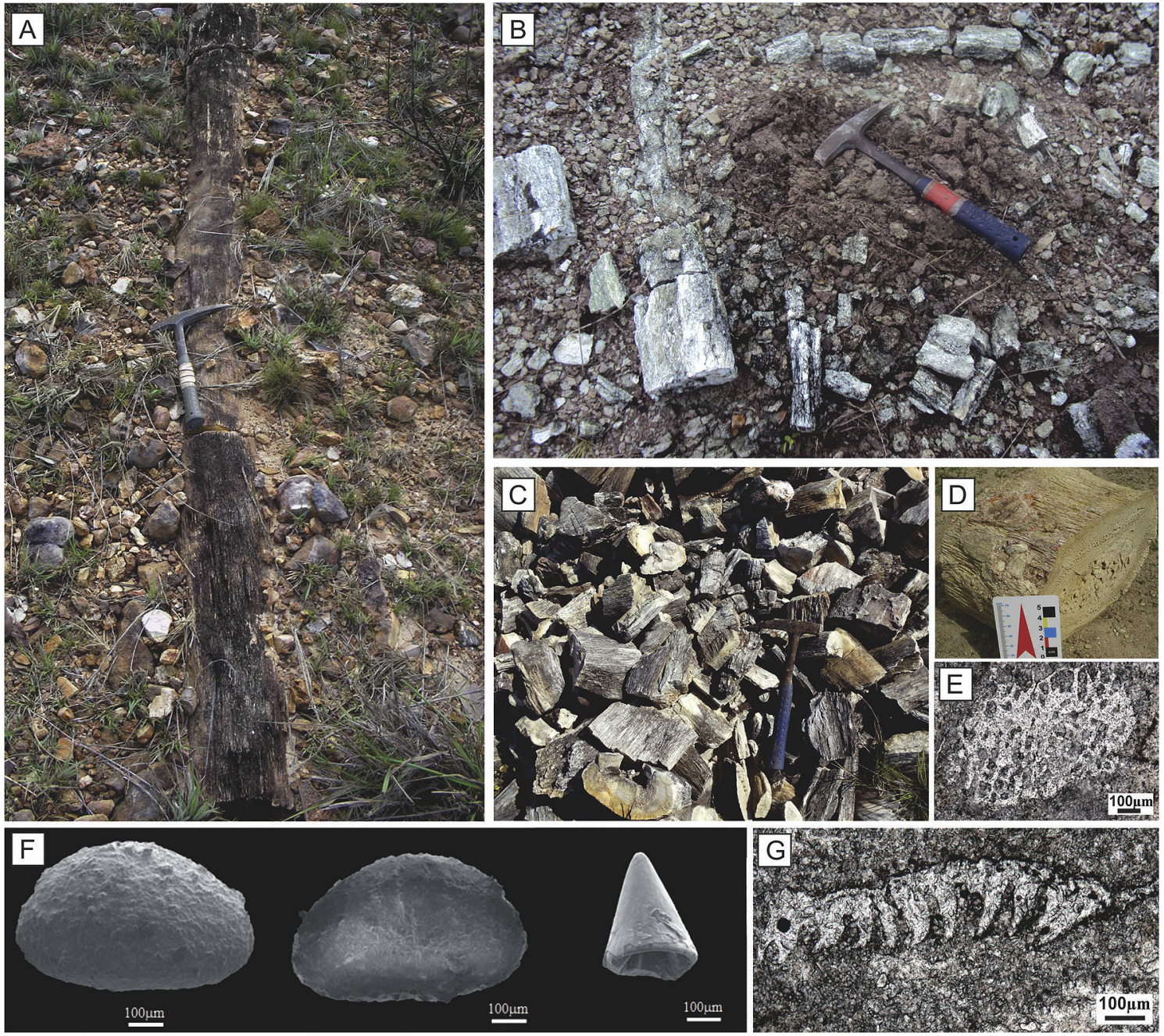

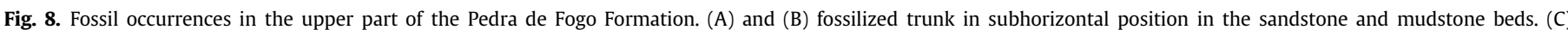

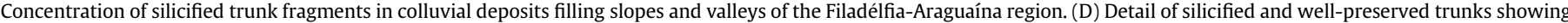

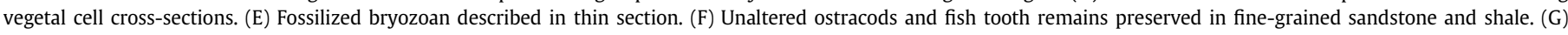
Scolecodonts identified in thin section.

armpits of bromeliads and interstices of sediments below the soil. Fish can be found in a wide variety of environments, from hypersaline to fresh water (Benton, 2005). We must emphasize that a lake with salinity variations can imitate marine conditions, especially lakes that are characterized by frequent expansion and contraction processes due to changes between arid and semi-arid conditions. The existence of cyclicity within a lacustrine depositional environment, with variations in the oxygen and salinity content, associated with events of expansion and contraction, support the presence of these individuals in the Pedra de Fogo lacustrine system.

4.1.2.3. Wadi/inundite deposits (FA3). FA3 occurs in the AraguaínaFiladélfia region forming flat beds approximately $7 \mathrm{~m}$ thick, truncated by sandstone bodies exhibiting concave-up geometry. The succession of outcrops occurs continuously exposed for dozens of meters and generally truncates the FA2 deposits. FA3 consists of matrix-supported conglomerates, medium to coarse sandstones intercalated with thin beds of mudstone, occurring as metric fining-upward cycles (Fig. 9A). This association is composed of trough cross-stratified conglomerate/sandstone (SCt), evenly parallel to undulate, laminated mudstone/siltstone (MSl), fine to medium-grained sandstone showing tabular cross-stratification (St), massive pebbly sandstone (Pm) and massive sandstone ( $\mathrm{Sm}$ ) (Fig. 9A-D).

The conglomerate/sandstone showing trough crossstratification is composed of angular grains (pebble and mediumgrained sand) showing a low sphericity and small-scale trough cross-stratification (sets of up to $20 \mathrm{~cm}$ ). The internal laminations locally exhibit convolute bedding. The fine to medium-grained sandstone showing tabular cross-stratification is moderately sorted and contains angular to subangular grains with a low sphericity. The boundaries of this set are in general evenly parallel or slightly inclined $\left(<3^{\circ}\right)$. The tabular cross-stratified sets are up to $0.5 \mathrm{~m}$ thick and the forests indicate paleocurrents to the E-SE (Fig. 9B). Mud drapes rarely occur in forests (Fig. 9E).

Medium-grained to pebbly sandstone showing massive bedding occurs at the base of fining-upward cycles, forming deposits exhibiting a tabular geometry (Fig. 9A). Silicified plant remains are associated with mudstone (Fig. 8B) at the top of fining-upward cycles and are rarely associated with sandstones (Fig. 8A). Wadi and inundite deposits are widely recognized in the geological record and generally concentrate around lake systems (Talbot and Allen, 1996). Wadis are ephemeral rivers associated with dry lake 

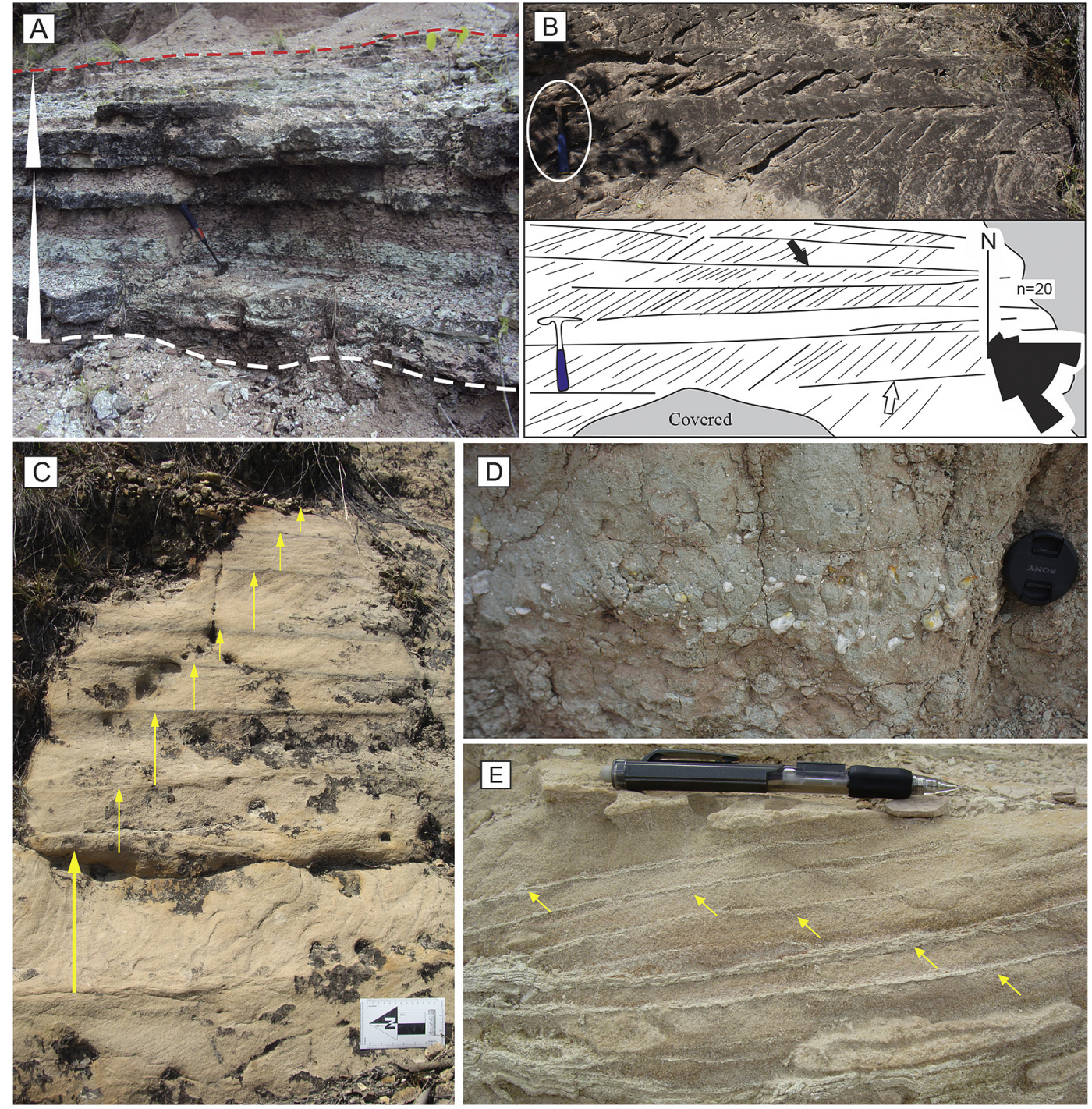

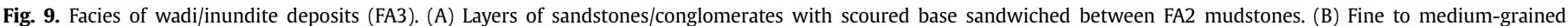

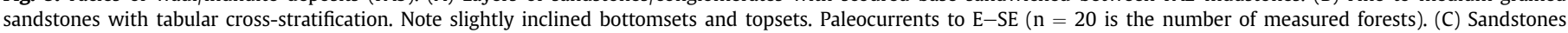

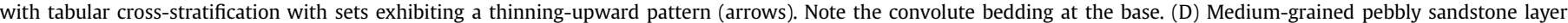
showing massive bedding. The clasts are silex and quartz (E) Fine sandstone showing cross-stratification. Observe thin and irregular mud drapes in forests (arrows).

systems, while inundites are associated with sheet flow deposits that enter the lake areas with a bedload discharge that decelerates in the deep areas, followed by the deposition of suspended sediments (Talbot and Allen, 1996; Seilacher, 1977). These deposits, related to flash flood episodes, caused a terrigenous influx into the lake. The reworking of coarse sediments from high-energy flows causes erosion of the underlying layers and generates deposits showing scoured bases associated with the migration of 3D and 2D bedforms under a lower flow-regime. In contrast, it seems that unchanneled ephemeral flows associated with flash flood events and rapid sedimentation have not been frequent in the Pedra de Fogo Lake.

The predominance of tabular and flat beds exhibiting internal evenly parallel stratification suggests extensive spreading of sediments during their deposition. Sheet flows produce flat, lenticular or laminated silt and sand layers, capped by mud drapes resulting from the dissipation of the flow (Hardie et al., 1978). The progressive decrease in grain size accompanied by the generation of lower flow-regime structures characterizes this facies succession (cf.
Miall, 1977; Stear, 1985). When flash flood events stop abruptly suspension predominates, leading to the migration of small ripples and massive deposition of thick shale packages, marking the top of fining-upward cycles (facies MSl).

\section{Discussion}

\subsection{Depositional model and final remarks}

The Pedra de Fogo Formation reflects a shallow lacustrine system represented by mudflats (FA1), nearshore (FA2) and wadi/ inundite (FA3) deposits developed in Western Gondwana during the Permian (Fig. 10). The Pedra de Fogo lake system was characterized by a regular increase and decrease of accommodation space as well as a high aggradation rate and low progradation rate resulting from the constant change in water depth due to climate and paleogeographic changes that occurred during the Permian Period. The arid conditions increased towards the Late Permian, while the silica increased in the Early and Middle Permian. Remains 


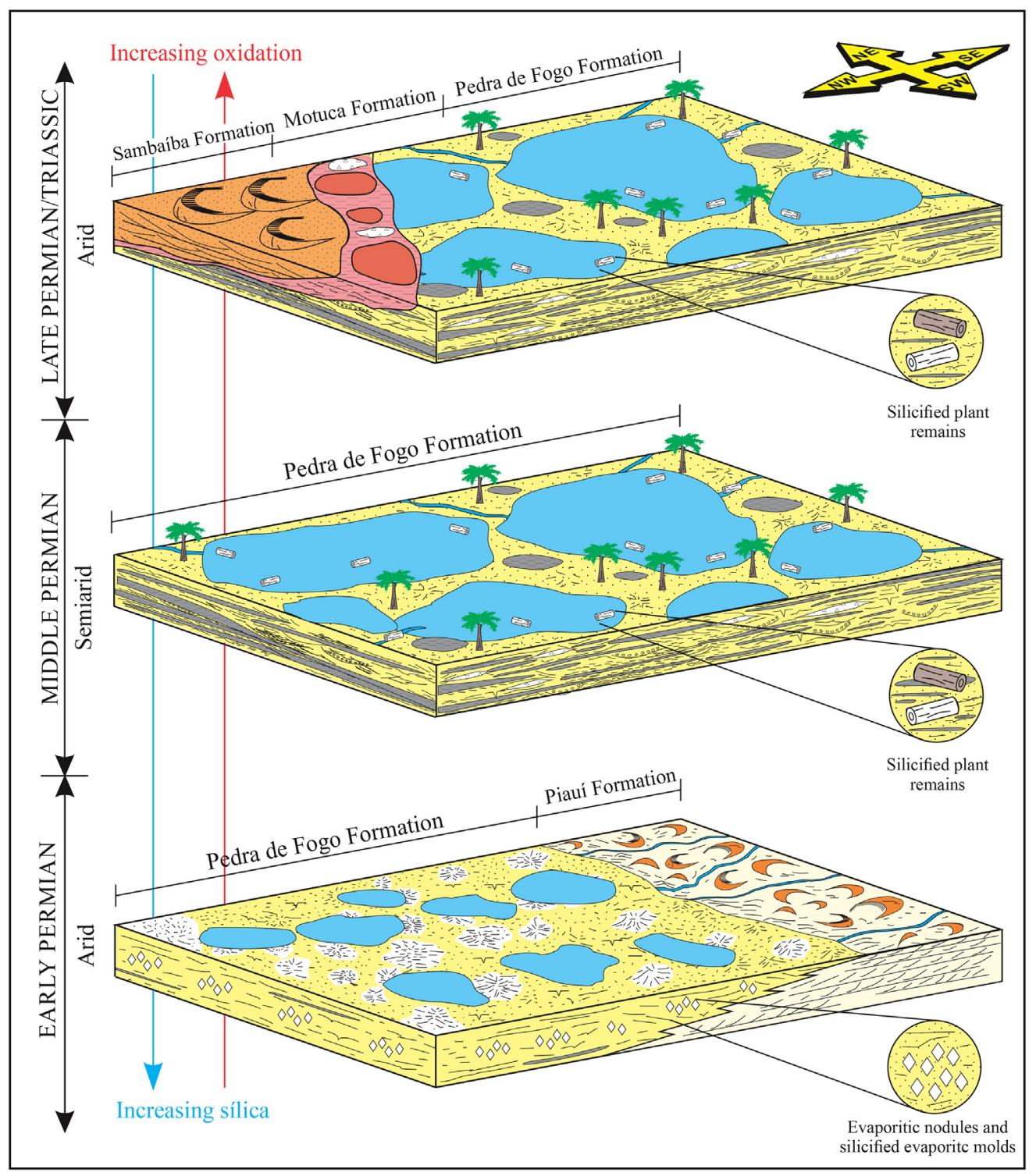

Fig. 10. Depositional model for the Pedra de Fogo Formation during the Parnaiba Basin Permian Period, Brazil.

of silicified wood suggest an abundance of silica in the sedimentary and/or diagenetic environment, which caused the rapid fossilization of wood fragments. The expansion of Permian flora in the Parnaíba Basin was associated with climate changes at the EarlyMiddle Permian boundary that established semiarid conditions.

The flora represented by silicified wood, mainly of the Psaronius genus, indicate a continental origin for the unit (Coimbra and Mussa, 1984; Mussa and Coimbra, 1987; Martins, 2000; Rößler and Galtier, 2002a, 2002b, 2003; Dias-Brito et al., 2007; Kurzawe et al., 2013; Tavares et al., 2014). Dino et al. (2002) suggested a continental origin for the Pedra de Fogo Formation deposits based on the abundance of continental palynomorphs and the scarcity of marine microplankton. The interpretation of a strictly continental system for the Pedra de Fogo Formation is supported also by the occurrence of amphibians (Cox and Hutchinson, 1991). The fossiliferous assembly found in this study is composed of fish remains, bryozoans, ostracods and scolecodonts, which corroborate the continental paleoenvironment previously interpreted.

Silica is an important marker for the lithostratigraphic recognition of the Pedra de Fogo Formation. It represents the main element in the depositional paleoenvironment that controlled the fossilization process during the Permian Period. The origin of silica in Permian strata is still unknown. An unusual episode of biogenic chert accumulation dating from the Late Permian to Early Triassic, which lasted approximately $30 \mathrm{My}$, may have been the main source of silica for the Pedra de Fogo Formation, which was called the Permian Chert Event (PCE) by Murchey and Jones (1992). Its beginning occurred around the Artinskian-Kungurian (end of Early Permian), extending during the Wordiano-Capitaniano (Middle Permian) and prevailing until the Changsingiano (Late Permian), when there was an abrupt interruption of the PCE.

Quartz dissolution processes realized by increasing the "pressure solution" (Pittman, 1972), diagenesis of clay minerals and weathering processes in a continental arid to semiarid and alkaline environment may have functioned as other sources of silica for the unit. Volcanic eruptions, related to intense continental collisions caused by the formation of the Pangaea Supercontinent, that occurred at the end of the Permian, known as the "Siberian Traps", are also indicated as a possible silica source (Campbell et al., 1992; Ziegler et al., 1997; Courtillot and Renne, 2003). 
However, this event dates from the Late Permian and is probably not related to the silica accumulation that took place in the Early and Middle Permian (Beauchamp and Baud, 2002). In lakes associated with faults and hydrothermal activities, alkaline hot springs can be an additional source of silica (Talbot and Allen, 1996). It is necessary to confirm if the inland seas were connected during the Permian Period.

The climatic modifications during the Permian are registered in the Pedra de Fogo deposits. At the end of this period, extreme conditions have been linked to the formation of Pangaea, which promoted the implementation of arid and hot climates as well as the development of desert and evaporitic environments inside the supercontinent (Scotese et al., 1999). However, the greatest extinction ever recorded on Earth, known as the Permian-Triassic $(\mathrm{P}-\mathrm{Tr})$. Extinction Event, doesn't seem to be registered in the unit. In the Late Permian, hot and arid climates were established again. The Pedra de Fogo Lake system was succeeded by the deposition of red beds of the Motuca Formation that was followed by the desert system of the Sambaíba Formation in the Triassic Period.

\section{Conclusions}

The Permian deposits of the Pedra de Fogo Formation were grouped into three facies associations (FA): mudflat (FA1), nearshore (FA2) and wadis/inundites (FA3), representative of a shallow lake system in the Permian Period of the Parnaíba Basin. Arid and hot climates predominated in the Early Permian causing the formation of mudflats dominated by siliciclastic sedimentation and subordinate evaporitic deposition as indicated by halite nodules and silicified evaporite casts that exhibit a popcorn-like structure.

In the Middle Permian, mild temperatures (semiarid climate) that allowed the proliferation of fauna and flora in humid regions adjacent to the lake system were established. Eventually, ephemeral rivers supplied large amount of sediments, deposited mainly in the marginal portions. Permian flora debris was transported postmortem by these flows and are important as they indicate ephemeral river paleocurrents during this period.

The Late Permian was characterized by a hot and arid climate due to the consolidation of the Pangaea Supercontinent that allowed the deposition of the Motuca Formation red bed sequences and the development of the Sambaíba Desert during the Triassic Period. Oxidizing conditions were common in the Late Permian, while silica was abundant in the Middle and Early Permian. The abundance of silica in the Early Permian can be related to the biogenic chert accumulation event during the Permian (Permian Chert Event - PCE), which lasted approximately 30 My and extended from the end of Early Permian to the beginning of the Late Permian.

Permian fossilized logs, identified as Psaronius, are excellent biostratigraphic markers for the upper Pedra de Fogo Formation and were preserved by rapid replacement of vegetal material with silica and quick burial in a process of eodiagenetic/synsedimentary fossilization. The recognized specimens, generally of small sizes, reflect a stressful environment, confined and connected to changes in salinity and regular terrigenous influx. The description for the first time of scolecodonts and bryozoans, in the Pedra de Fogo Formation opens possibilities for further paleoenvironmental studies.

Phases of contraction and expansion characterized the Pedra de Fogo Lake, resulting from climatic changes that influenced not only the pattern of sedimentation, but also the fauna and flora preserved in Western Gondwana, being one of the most significant records of the Late Permian.

\section{Acknowledgments}

Thanks are expressed to CNPq (Conselho Nacional de Desenvolvimento Científico e Tecnológico) for granting a Master's scholarship to the first author, CNPq: (133932/2013-3) to UFPA (Universidade Federal do Pará), especially to PPGG (Programa de Pós-Graduação em Geologia e Geoquímica) for the infrastructure supplied, and to the Laboratório de Difração de Raios-X (UFPa) and Laboratório de Microscopia Eletrônica de Varredura (LabMEVUFPa) for support in analyses. The authors also wish to thank Ms. Rejane Amaral who assisted in the proof-reading of the manuscript. Finally, we wish to thank Prof. Dr. Werner Truckenbrodt by discussions that contributed to improve the article and Anna A. Nogueira for assistance in the identification of the fossils.

\section{References}

Abrantes, F.R., Nogueira, A.C.R., 2013. Reconstituição paleoambiental das formações Motuca e Sambaíba, Permo-Triássico da Bacia do Parnaíba no sudoeste do Estado do Maranhão, Brasil. Geol. Usp. Sér. Cient. São Paulo 13 (3), 6-82. Setembro 2013.

Adams, A.E., Mackenzie, W.S., Guilford, C., 1984. Atlas of Sedimentary Rocks under the Microscope. Longman, Harlow, p. 140.

Aguiar, G.A., 1964. Semi-detalhe da região de sudoeste de Balsas. PETROBRAS, DIREX/RENOR, Belém, Relatório 21BM, p. 40.

Aguiar, G.A., Nahass, S., 1969. Mapa Geológico da Bacia do Maranhão. In: PETROBRÁS, RENOR-direx, Relatório, 371, p. 1.

Amiel, A.J., Friedman, G.M., 1971. Continental sabkhas in Arava Valley between Dead sea and Red sea: significance for origin of evaporites. Am. Assoc. Pet. Geol. Bull. 55 (4), 581-592.

Andrade, L.S., Nogueira, A.C.R., Bandeira, J., 2014. Evolução de um sistema lacustre árido Permiano, parte superior da Formação Pedra de Fogo, borda oeste da Bacia do Parnaíba. Geol. Usp. Sér. Cient. São Paulo 14 (4), 3-60 (Dezembro).

Barbosa, O., Gomes, F.A., 1957. Carvão mineral na Bacia do Tocantins-Araguaia. In: DNPM, Boletim Do Dep. Nac. Prod. Mineral, № 174, p. 35.

Beauchamp, B., Baud, A., 2002. Growth and demise of Permian biogenic chert along northwest Pangea: evidence for end-Permian collapse of thermohaline circulation. Palaeogeogr. Palaeoclimatol. Palaeoecol. 184, 37-63.

Benton, M.J., 2005. Vertebrate Palaeontology, $3^{\text {a }}$ ed. Blackwell Science, Ltd, p. 455.

Briere, P.R., 2000. Playa, playa lake, sabkha: proposed definitions for old terms. J. Arid Environ. 45, 1-7.

Caldas, E.B., Mussa, D., Lima Filho, F.P., Rosler, O., 1989. Nota sobre a ocorrência de uma floresta petrificada de idade permiana em Teresina, Piauí. São Paulo, Boletim do Instituto de Geociências. Publicação Espec. 7, 69-87.

Campbell, I.H., Czamanske, G.K., Fedorenko, V.A., Hill, R.I., Stepanov, V., 1992. Synchronism of the siberian traps and the Permian-Triassic boundary. Science 258 (11), 1760-1763.

Capretz, R.L., Rohn, R., 2013. Lower Permian stems as fluvial paleocurrent indicators of the Parnaíba Basin, northern Brazil. J. S. Am. Earth Sci. 45, 69-82.

Caputo, M.V., 1984. Stratigraphy, Tectonics, Paleoclimatology and Paleogeography of Northern Basins of Brazil. Thesis (doctorate). University of Califórnia, Santa Bárbara, p. 586.

Coimbra, A.M., Mussa, D. 1984. Associação lignitatoflorística na Formação Pedra de Fogo (Arenito Cacunda), bacia do Maranhão, Piauí, Brasil. In: SBG (Ed.), Cong. Bras. Geol., 33, Rio de Janeiro, Anais, 2, pp. 591-605.

Collinson, J.D., 1969. The sedimentology of the Grindslow shales and the Kinderscout Grit: a deltaic complex in the Namurian of northern England. J. Sediment. Petrol. 39, 194-221.

Courtillot, V., Renne, P., 2003. On the ages of flood basalt events. Comp. Rendus Geosci. 335 (1), 113-140.

Cox, C.B., Hutchinson, P., 1991. Fishes and amphibians from the Late Permian Pedra de Fogo Formation of northern Brazil. Paleontology 34 (3), 561-573.

Cunha, F.M.B., 1964. Geologia do sudeste de Balsas. PETROBRAS, DIREX/RENOR, Belém. Relatório 224M, p. 46.

Demicco, R.V., Hardie, L.A., 1994. Sedimentary Structures and Early Diagenetic Features of Shallow Marine Carbonate Deposits. In: Oklahoma, SEPM Atlas of Sedimentary Structures, p. 265.

Dias-Brito, D., Rohn, R., Castro, J.C., Dias, R.R., Rößler, R., 2007. Floresta Petrificada do Tocantins Setentrional - O mais exuberante e importante registro florístico tropical-subtropical permiano no Hemisfério Sul. In: Winge, M., Schobbenhaus, C., Berbet-Born, M., Queiroz, E.T., Campos, D.A., Souza, C.R.G., Fernanes, A.C.S. (Eds.), Sítios Geológicos e Paleontológicos do Brasil, pp. 1-16.

Dino, R., Antonioli, L., Braz, S.M.N., 2002. Palynological data from the Trisidela Member of Upper Pedra de Fogo Formation ("Upper Permian") of the Parnaíba Basin, northeastern Brazil. Rev. Bras. Paleontol. 24-35.

Faria Jr., Truckenbrodt, 1980b. Estromatólitos na Formação Pedra de Fogo, Permiano, Bacia do Maranhão. In: SBG (Ed.), Cong. Bras. Geol., 31, Balneário Camboriú, Anais, 5, pp. 3056-3067.

Faria Jr., Truckenbrodt, 1980a. Estratigrafia e petrografia da Formação Pedra de Fogo - permiano da Bacia do Maranhão. In: SBG (Ed.), Cong. Bras. Geol., 31, Balneário 
Camboriú, Anais, 2, pp. 740-754.

Faria Jr., L.E.C., 1979. Estudo sedimentológico da Formação Pedra de Fogo - Permiano - Bacia do Maranhão. Dissertação de Mestrado. Núcleo de Ciências Geofísicas e Geológicas, Universidade Federal do Pará, p. 57.

Figueiras, A.J.M., Martins, M.S.C., 1985. Dolomitizaçao dos carbonatos permianos da Formacao Pedra de Fogo na regiáo de São Joao do Araguaia-PA.

Góes, A.M., 1995. A Formação Poti (Carbonífero Inferior) da Bacia do Parnaíba. Tese de doutorado. Universidade de São Paulo, São Paulo, p. 171.

Góes, A.M.O., Feijó, F.J., 1994. Bacia do Parnaíba. Rio de Janeiro, PETROBRÁS. Bol. Geociências Petrobras 8 (1), 57-67.

Hardie, L.A., Smoot, J.P., Eugster, H.P., 1978. Saline lakes and their deposits. In: Matter, A., Tucker, M.E. (Eds.), Modern and Ancient Lake Sediments, Spec. Publ. Int. Ass. Sediment., 2, pp. 7-42.

Kendall, A.C., 1992. Evaporites. In: Walker, R.G., James, N.P. (Eds.), Facies Models: Response to Sea Level Change. Geol. Ass. Canada, pp. 375-409.

Kendall, C.G.S.T.C., Warren, J., 1987. A review of the origin and setting of tepees and their associated fabrics. Sedimentology 34, 1007-1027.

Kiehl, J.T., Shields, C.A., 2005. Climate simulation of the latest Permian: Implications for mass extinction. Geology 33 (9), 757-760.

Koeberl, C., Farley, K.A., Peucker-Ehrenbrink, B., Sephton, M.A., 2004. Geochemistry of the end-Permian extinction event in Austria and Italy: no evidence for an extraterrestrial component. Geology 32 (12), 1053-1056.

Kurzawe, F., Iannuzzi, R., Merlotti, S., Rößler, R., Noll, R., 2013. New gymnospermous woods from the permian of the Parnavba Basin, northeastern Brazil, part I: Ductoabietoxylon, Scleroabietoxylon and Parnaiboxylon. Rev. Palaeobot. Palynol 195, 37-49.

Lima, E.A.M., Leite, J.F., 1978. Projeto estudo global dos recursos Minerais da Bacia Sedimentar do Parnaíba. Integração geológico-metalogenética. DNPM-CPRM Etapa III Recife Relatório Final 16, 212.

Lowenstein, T.K., Hardie, L.A., 1985. Criteria for the recognition of salt pan evaporates. Sedimentology 32, 627-644.

Martins, R.A., 2000. Fósseis de vegetais da Formação Pedra de Fogo: aspectos taxonômicos, mineralogia e composição química. Dissertação de Mestrado. Centro de Geociências, Universidade Federal do Pará, p. 92.

Mckee, M.D., Weir, G.W., 1953. Terminology for stratification and cross-stratification in sedimentary rocks. Geol. Soc. Am. Bull. 64 (4), 381-390.

Meyer, K.M., Kump, L.R., Ridgwell, A., 2008. Biogeochemical controls on photic-zone euxinia during the end-Permian mass extinction. Geology 36 (9), 747-750.

Miall, A.D., 1977. A review of the braided-river deposicional environment. Earth Sci. Rev. 13 (1), 1-62.

Moore, B., 1964. Geological Reconnaissance of the Southern Margin of the Maranhão Basin. PETROBRÁS, DIREX/RENOR, Belém, Relatório 216M, p. 46.

Murchey, B.L., Jones, D.L., 1992. A mid-Permian chert event: widespread deposition of biogenic siliceous sediments in coastal, island arc and oceanic basins. Palaeogeogr. Palaeoclim. Palaeoecol. 96, 161-174.

Mussa, D., Coimbra, A.M., 1987. Novas perspectivas de comparação entre as tafofloras permianas (de lenhos) das bacias do Parnaíba e do Paraná. In: SBP (Ed.), Cong. Bras. Paleontologia, 10, Rio de Janeiro, Anais, 2, pp. 901-923.

Northfleet, A.A., 1965. Semi-detalhe da região noroeste do alto Parnaíba. PETROBRÁS, DIREX/RENOR, Belém, Relatório 240M, p. 52.

Ojeda, H.A., Bembom, F.C., 1966. Mapeamento geológico de semi-detalhe do sudoeste de Riachão. PETROBRÁS, DIREX/RENOR, Belém, Relatório 260M, p. 67.

Ojeda, H.A., Perillo, I.A., 1967. Geologia do sudoeste de Carolina. PETROBRÁS, DIREX/ RENOR, Belém, Relatório 270M, p. 53.

Oliveira, M.A., 1961. Reconhecimento geológico no flanco oeste da Bacia do Maranhão. PETROBRAS, DIREX/RENOR, Belém, Relatório. 171M, p. 77.

Pittman, E.D., 1972. Diagenesis of quartz in sandstones as revealed by scanning electron microscopy. J. Sediment. Petrol. 42, 507-519.

Plummer, F.B., 1946. Report on Maranhão-piauí Geosyclinae. PETROBRÁS, DIREX/
RENOR, Belém, Relatório 1M, p. 83.

Reading, H.G. Levell, B.K., 1996. Controls on the sedimentary rock record. In: Reading, H.G. (Ed.), Sedimentary Environments: Processes, Facies and Stratig raphy, third ed. Blackwell, Oxford, pp. 5-36.

Rößler, R., Galtier, J., 2002a. First Grammatopteris tree ferns from the Southern Hemisphere - new insights in the evolution of the Osmundaceae from the permian of Brazil. Rev. Palaeobot. Palynol. 121, 205-230.

Rößler, R., Galtier, J., 2002b. Dernbachia brasiliensisgen. nov.et sp. nov. - a new smal tree fern from the Permian of NE Brazil. Rev. Palaeobot. Palynol. 122, 239-263.

Rößler, R., Galtier, J., 2003. The first evidence of the fern Botryopteris from the Permian of the Southern Hemisphere reflecting growth form diversity. Rev. Palaeobot. Palynol. 127, 99-124.

Scotese, C.R., Boucot, A.J., Mckerrow, W.S., 1999. Gondwanan palaeogeography and palaeoclimatology. J. Afr. Earth Sci. 28 (1), 99-114.

Seilacher, A., 1977. Events and their signatures - an Overview. In: Einsele, G., Ricken, W., Seilacher, A. (Eds.), Cycles and Events in Stratigraphy. SpringerVerlag, Berlin, pp. 222-226.

Small, H.I., 1914. Geologia e supprimento d'agua subterranea no Piauhy e parte do Ceará. Insp. Obras Contra Seccas, Ser. Geol. 32, 1-186.

Stear, W.M., 1985. Comparison of the bedform distribution and dynamics of modern and ancient flood deposits in the southwestern Karoo region, South Africa. Sediment. Geolol. 45, 209-230.

Summerfield, M.A., 1983. Silcrete. In: Goudie, A.S., Pye, K. (Eds.), Chemical Sediments and Geomorphology. Academic Press, London, pp. 59-91.

Talbot, M.R., Allen, P.A., 1996. Lakes. In: Reading, H.G. (Ed.), Sedimentary Environments: Processes, Facies and Stratigraphy, third ed. Blackwell, Oxford, pp. 83-123.

Tavares, T., Rohn, R., Rößler, R., Noll, R., 2014. Petrified Marattiales pinnae from the lower permian of North-Western Gondwana (Parnaíba Basin, Brazil). Rev. Palaeobot. Palynol. 201, 12-28.

Taylor, P.D., December 2005. Bryozoans and paleoenvironmental interpretation. J. Palaeontol. Soc. India. Gold. Jubil. 50 (2), 1-11.

Thiry, M., 1999. Diversity of continental silicification features: examples from the Cenozoic deposits in the Paris Basin and neighbouring basement. In: Thiry, M. Simon-Coinçon, R. (Eds.), Palaeoweathering, Palaeosurfaces and Related Continental Deposits, Special Publication 27, International Association of Sedimentologists. Blackwell Science, Oxford, pp. 87-127.

Traverse, A., 2007. Paleopalynology, 2rd ed. In: Tópicos Em Geobiology 28. Springer Dordrecht, Holanda, p. 813

Tucker, M.E., 2003. Sedimentary Rocks in the Field, third ed. Wiley, Chichester, p. 234.

Vaz, P.T., Resende, N.G.A.M., Wanderley Filho, J.R., Travassos, W.A., 2007. Bacia do Parnaíba. Rio de Janeiro, PETROBRÁS. Bol. Geociências 15 (2), 253-263.

Walker, R.G., 1992. Facies, facies models and modern stratigrahic concepts. In: Walker, R.G., James, N.P. (Eds.), Facies Models: Response to Sea Level Change. Geol. Ass. Canada, pp. 1-14

Walker, R.G., 2006. Facies models revisited: an introduction. In: Posamentier, H.W Walker, R.G. (Eds.), Facies Models Revisited. Society for Sedimentary Geology (SEPM)

Zalán, P.V., 1991. Influence of pre-Andean orogenies on the paleozoic intracratonic basins of South America. In: Simpósio Bolivariano: Exploración Petrolera en las Cuencas Subandinas 4. Memórias, Bogotá, ACGGP, Trabajo 7, p. 20.

Zharkov, M.A., Chumakov, N.M., 2001. Paleogeography and sedimentation settings during Permian-triassic reorganizations in biosphere. Stratigr. Geol. Correl. 9 (4), 340-363.

Ziegler, A.M., Hutver, M.L., Rowley, D.B., 1997. Permian world topography and climate. In: Martini, I.P. (Ed.), Late Glacial and Postglacial Environmental Changes - Quaternary, Carboniferous-permian and Proterozoic. Oxford University Press, New York, pp. 111-146. 